point of view based on scientific principles; (2) the development of a desire to do something about social problems; (3) the development of ability to work co-operatively on the analysis and solution of problems. In the schemes of work there is an attempt to integrate the science subjects and also to achieve a newer synthesis of the sciences with other branches of knowledge such as the social studies, history, English, and so on.

All this is not new to the progressive teacher in a British secondary school, where 'reality in the classroom', 'projects' and social studies are being developed. Such treatment is particularly useful for the non-specialist in science, but it may be that a word of warning is necessary. Since 1902 a general high level in science has been built up in British grammar schools, and many of the 'public schools' have a somewhat longer tradition in these matters. No doubt 'project' and 'reality' methods can effectively replace the old 'heurism', and there is still room for a wider knowledge of the applications of science to the improvement of society; but the loss to science standards in Great Britain would be incalculable were anything to replace the sound training in fundamental principles and laboratory measurements which has characterized most of the grammar school science during more than four decades.

W. L. SUMNER

\section{A CHEMICAL TECHNOLOGIST LOOKS AHEAD}

\section{Farmer Victorious}

Money, Mart and Mother Earth. By William J. Hale. Pp. xii + 241. (New York: Coward-McCann, Inc., 1949.) 3 dollars.

$\mathrm{T}$ HE author of this book, Dr. W. J. Hale, was chairman of the Division of Chemistry and Technology of the National Research Council, Washington, D.C., and is now consultant to an important American chemical company. Like many others, he feels that the blessings that our fathers expected from the enormous developments of science and technology have not materialized; something has gone wrong. He considers he has discovered the fault-the money-lending on which the trading and banking systems of the world are based. The elimination of this fault requires the abolition of inter. national trade and the re-organisation of the nations of the world into four blocks or sections: AngloAmerican, Latin-Teutonic, Slav, and Mongolian, each of which would be self-sufficing and would have no occasion to trade with the others, though some tourist traffic would apparently be permitted. All small nations would simply disappear ; the pound sterling would vanish and be replaced by the dollar, the U.S.S.R. would be encouraged to expand still further and acquire "a deep southern domain", and Africa would largely become an appendage of the Latin-Teutonic section. India is not mentioned, being apparently too small for consideration. With all this part of the story, and the denunciations of business men, "crackpot" politicians, and the supposed "tame" scientific workers who meekly obey them, we need not concern ourselves.

The technological part of the book is based on the thesis that the farm is a much better source of raw materials for the chemical manufacturer than coal or oil, inasmuch as its resources are inexhaustible. "We need to apply ourselves more diligently," the author says, "to harness the four million kilo-watt hours of the sun's energy that falls dajly on every square mile of the earth's surface." The statement is typical of the whole book. The plant synthesizes carbohydrates which can be fermented to produce ethyl alcohol, which is not only an excellent source of power but also a starting material for making synthetic rubber and many other things. Oat hulls and corn cobs yield furfurol, out of which nylon can be made; castor oil seems even more promising. Each type of plastic, however, requires its own crop. Factories should be set up to deal with all farming products, even weeds; direct food production would become a subsidiary activity, and meat would be replaced by synthetic amides. Such food as was grown must be produced without the use of synthetic fertilizers; only composts, the trace and 'basic' elements, and, apparently, nitrogenous fertilizers, being permitted. A special chewing.gum would ensure ample supplies of vitamins and other essentials.

Those interested in blueprints for the 'New Age' may like to add this to their collection; it differs from those of Aldous Huxley, Vogt and Osborn in forecasting illimitable supplies of farm products which can be worked up into all things needed by man, though it does not say how these vast quantities can be obtained.

E. J. RusSELI

\section{ELECTROMAGNETIC INDUCTION}

Faraday's Discovery of Electromagnetic Induction By Thomas Martin. Pp. $160+4$ plates. (London : Edward Arnold and Co., 1949.) 9s, net.

IICHAEL FARADAY carried out the greater 1 part of his experimental researches within the Royal Institution, Albemarle Street, London, and it was characteristic of him that he made notes, in diary form, of his investigations and occasionally his speculations. Mr. Thomas Martin, general secretary of the Royal Institution since 1929, edited the printed version of "Faraday's Diary" published during 1932-36 in seven volumes. While engaged on this task, Mr. Martin delved deeply into Faraday's published papers and other contemporary and later sources of information. In the present little work, he has selected one of Faraday's major investigations -and perhaps his most important-namely, electromagnetic induction, and presented it in the light of contemporary views of the nature of electricity and magnetism. By quoting extensively from the "Diary", he enables the reader to follow Faraday's thoughts and work on the subject over a period of years, culminating in about six months of almost continuous work in late 1831 and early 1832 which served to establish the main facts of electromagnetic induction, the basis of modern electrical engineering. Having discovered the effect on August 29, 1831, Faraday quickly verified his observations, and then passed on to obtain a flow of induced electricity by means of a rotating copper disk and finally extended the work to induction by the earth's magnetism.

The book is illustrated by reproductions of many of the quaint little sketches drawn by Faraday in his notes and by photographs of apparatus he used which is still in the keoping of the Royal Institution. 